JURNAL ILMIAH MANAJEMEN BISNIS DAN INOVASI UNIVERSITAS SAM RATULANGI

\title{
IMPLEMENTASI KEPEMIMPINAN TNI TIPE STRATEGIS DALAM PERCEPATAN PENANGANAN COVID-19 DAN PEMULIHAN EKONOMI NASIONAL GUNA MENINGKATKAN KESEJAHTERAAN MASYARAKAT DALAM RANGKA TERWUJUDNYA INDONESIA TANGGUH
}

Purboyo, Gemma Eka Putra, Rina Marlina

Sekolah Staf Dan Komando Angkatan Laut, Jakarta

A R T I C LE IN F O

\section{Keywords: \\ Leadership, Handling Covid-19, National Economic Recovery and Community Welfare}

Kata Kunci: Kepemimpinan, Penanganan Covid-19, Pemulihan Ekonomi Nasional dan Kesejahteraan Masyarakat

Corresponding author:

Purboyo Ppurboyo37@gmail.com
Abstract: The long journey of the Indonesian nation has proven its resilience in facing various kinds of challenges. The resilience of the Indonesian nation itself is currently being tested in the face of the Covid19 pandemic. The Indonesian government has made every effort to get out of the crisis caused by this pandemic by accelerating the handling of Covid-19 and restoring the national economy. In accelerating the handling of Covid-19 and the recovery of the national economy, a leader is needed who can bring the Indonesian people out of the problems of the pandemic and economic crisis. A person's ability to anticipate, dream, maintain flexibility, think strategically and work with others to initiate change that will create a better future for the organization.

Abstrak: Perjalanan panjang bangsa Indonesia telah membuktikan ketangguhan dalam menghadapi berbagai macam tantangan. Ketangguhan bangsa Indonesia sendiri saat ini sedang diuji dalam menghadapi pandemi Covid-19. Pemerintah Indonesia telah melakukan segala upaya untuk bisa keluar dari krisis akibat pandemi ini melalui percepatan penanganan Covid-19 dan pemulihan ekonomi nasional. Dalam percepatan penanganan Covid-19 dan pemulihan ekonomi nasional dibutuhkan sosok pemimpin yang dapat membawa rakyat Indonesia keluar dari permasalahan pandemi dan krisis ekonomi. Kemampuan seseorang untuk mengantisipasi, memimpikan, mempertahankan fleksibilitas, berpikir secara strategis dan bekerja dengan orang lain untuk memulai perubahan yang akan menciptakan masa depan yang lebih baik bagi organisasi. 


\section{PENDAHULUAN}

Perjalanan panjang bangsa Indonesia telah membuktikan ketangguhan dalam menghadapi berbagai macam tantangan. Ketangguhan bangsa Indonesia sendiri saat ini sedang diuji dalam menghadapi pandemi Covid-19. Pemerintah Indonesia telah melakukan segala upaya untuk bisa keluar dari krisis akibat pandemi ini melalui percepatan penanganan Covid-19 dan pemulihan ekonomi nasional. Dalam percepatan penanganan Covid-19 dan pemulihan ekonomi nasional dibutuhkan sosok pemimpin yang dapat membawa rakyat Indonesia keluar dari permasalahan pandemi dan krisis ekonomi. Setelah satu tipe kepemimpinan yang ada yaitu kepemimpinan tipe strategi harus di implementasikan dalam percakapan penanganan Covid-19 dan pemulihan ekonomi nasional guna mewujudkan Indonesia tangguh.

Kondisi saat ini adalah negara-negara di seluruh dunia sedang menghadapi permasalahan yang sama yaitu pandemi Covid-19 termasuk Indonesia. Pemerintah Indonesia sedang melakukan segala upaya untuk menekan laju pandemi covid-19 melalui penetapan kebijakan dan aturan seperti pelaksanaan protokol kesehatan. Saat ini pemerintah sedang melaksanakan program vaksinasi nasional secara bertahap. Segala upaya yang dilaksanakan diiringi dengan program pemulihan ekonomi nasional. Kondisi yang diharapkan adalah segera berakhirnya pandemi Covid19 di Indonesia melalui pelaksanaan protokol kesehat yang ketat guna memutus rantai penularan Covid-19 dan program vaksinasi nasional untuk membentuk kekebalan tubuh masyarakat terhadap virus Covid-19. Dibidang ekonomi sendiri, kondisi yang diharapan adalah pulihnya perekonomian nasional melalui pertumbuhan ekonomi yang tinggi sesuai target pemerintah. Untuk bisa mencapai kondisi yang diharapkan maka dibutuhkan sosok pemimpin yang memiliki tipe kepemimpinan strategi agar dapat mengambil langkah-langkah strategi dengan tujuan mencapai kondisi yang diharapkan dengan pandemi Covid-19. Akan tetapi permasalahan yang dihadapi saat ini adalah belum terlaksananya implementasi kepemimpinan tipe strategis dalam percepatan penanganan Covid-19 dan pemulihan ekonomi nasional guna terwujudnya Indonesia tangguh.

Untuk bisa mewujudkan kondisi yang diharapkan yaitu terbebasnya negara Indonesia dari pandemi Covid-19 dan perekonomian nasional yang kembali membaik maka permasalahan yang ada saat ini harus diselesaikan. Pemecahan masalah terkait belum terlaksananya implementasi kepemimpinan tipe strategis adalah melaksanakan regenerasi kepemimpinan yang cepat dan berkesinambungan, meningkatkan kualitas pemimpin, mengoptimalkan sinergitas dan meningkatkan kemampuan pengambilan keputusan strategis yang cepat dan tepat. Dengan 
terlaksananya implementasi kepemimpinan tipe strategis dalam percepatan penanganan Covid-19 dan pemulihan ekonomi nasional maka akan terwujud Indonesia tangguh.

\section{Metode}

Teori Kepemimpinan Strategis.

Kepemimpinan strategis adalah kemampuan seseorang untuk mengantisipasi, memimpikan, mempertahankan fleksibilitas, berpikir secara strategis dan bekerja dengan orang lain untuk memulai perubahan yang akan menciptakan masa depan yang lebih baik bagi organisasi (https://www.kompasiana.com/habsulnurhadi/, 2012). Kepemimpinan strategis merupakan suatu proses memberikan arah dan inspirasi yang diperlukan untuk membuat dan melaksanakan visi organisasi, misi, dan strategi untuk mencapai tujuan organisasi. Kepemimpinan strategis harus melibatkan manajer di bagian atas, tengah, dan tingkat yang lebih rendah dari organisasi. Pemimpin strategis yang efektif antara lain memiliki keterampilan untuk:

1) Mengantisipasi dan meramalkan kejadian dalam lingkungan eksternal organisasi yang memiliki potensi untuk mempengaruhi kinerja organisasi,

2) Mencari dan mempertahankan keunggulan kompetitif dengan membangun kompetensi inti dan memilih pasar yang tepat untuk bersaing,

3) Mengevaluasi implementasi strategi dan hasil secara sistematis, dan membuat penyesuaian strategis,

4) Membangun tim karyawan yang sangat efektif, efisien, dan termotivasi,

5) Menentukan tujuan dan prioritas yang tepat untuk mencapainya, serta,

6) Menjadi komunikator yang efektif.

\section{Hasil dan Pembahasan}

Indonesia tangguh merupakan suatu kondisi dimana bangsa Indonesia yang sudah menjalani perjalanan waktu yang sangat panjang mampu melewati setiap tantangan dan permasalahan yang dihadapi oleh bangsa ini dari masa ke masa. Indonesia tangguh dalam kondisi saat ini adalah sedang menghadapi permasalahan pandemiCovid-19 dan tantangan untuk bisa segera terbebas dari pandemi tersebut melalui percepatan penanganan Covid-19 dan pemulihan ekonomi nasional. Dalam usaha mewujudkan kondisi Indonesia tangguh dibutuhkan sosok 
pemimpin yang mampu menjadi leader mempengaruhi dan membawa rakyat untuk bisa melakukan segala usaha mencapai tujuan tersebut dengan tipe kepemimpinan yang dimilikinya.

TNI sebagai lembaga pemerintah memiliki peran penting dalam mewujudkan kondisi Indonesia tangguh di situasi pandemiseperti ini. Agar kepemimpinan TNI dapat berperan besar dalam segala usaha ini maka permasalahan yang ada terkait kepemimpinan TNI harus dapat diselesaikan dengan solusi yang tepat. Untuk mengimplementasikan kepemimpinan TNI tipe strategis dalam percepatan penanganan Covid-19 dan pemulihan ekonomi nasional guna terwujudnya Indonesia tangguh maka perlu dilaksanakan pemecahan masalah melalui penetapan kebijakan, perumusan strategi yang ditindaklanjuti dengan pelaksanaan upaya-upaya terkait dengan tetap memperhatikan aspek-aspek yang mempengaruhi dalam pengambilan keputusan tersebut. Dalam pemecahan masalah ini menggunakan analisis studi kepustakaan dari teori-teori terkait dan pengalaman kedinasan di lingkungan TNI.

1. Pemecahan masalah.

Pemecahan masalah adalah suatu proses terencana yang perlu dilaksanakan agar memperoleh penyelesaian tertentu dari sebuah masalah yang mungkin tidak didapat dengan segera. Pendapat lainnya menyatakan bahwa pemecahan masalah sebagai usaha mencari jalan keluar dari suatu kesulitan (Muchlisin Riadi, 2016). Tahapan dalam pemecahan masalah yang akan dilakukan adalah sebagai berikut:

a. Penetapan kebijakan.

b. Perumusan strategi

c. Pelaksanaan upaya-upaya terkait sebagai penjabaran dari strategi yang sudah ditetapkan.

Perumusan kebijakan sangat diperlukan untuk dijadikan pedoman dalam menentukan strategi pencapaian tujuan sebelum dibentuk dalam upaya-upaya yang nyata. Bentuk pemecahan masalah merupakan rumusan dalam mewujudkan kondisi yang diharapkan yang berisi kebijakan, strategi, dan upaya. Sebagai pemecahan masalah, maka akan dirumuskan dan disusun kebijakan, strategi dan upaya. Perumusan kebijakan sebagai solusi dalam pemecahan masalah yang terdiri atas pokok persoalan dengan mempertimbangkan faktor peluang dan kendala sesuai dengan indikator keberhasilan yang secara ringkas disajikan dalam tabel berikut: 


\begin{tabular}{|c|c|}
\hline $\begin{array}{l}\text { Pokgk } \\
\text { persoalan. }\end{array}$ & 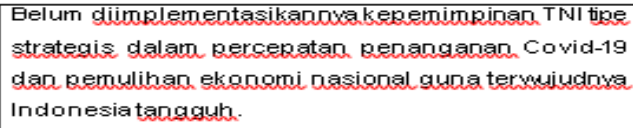 \\
\hline $\begin{array}{l}\text { Whasalab } \\
\text { yang } \\
\text { diteroukan. }\end{array}$ & 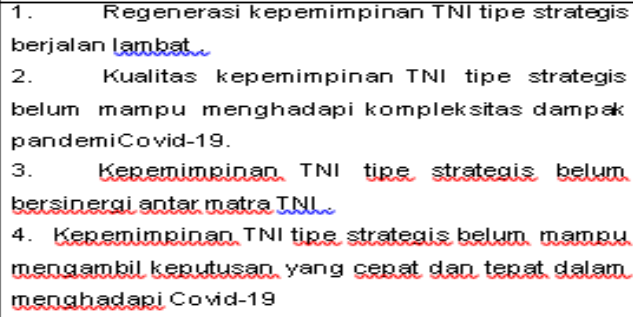 \\
\hline $\begin{array}{l}\text { Faktor } \\
\text { ekstemal }\end{array}$ & 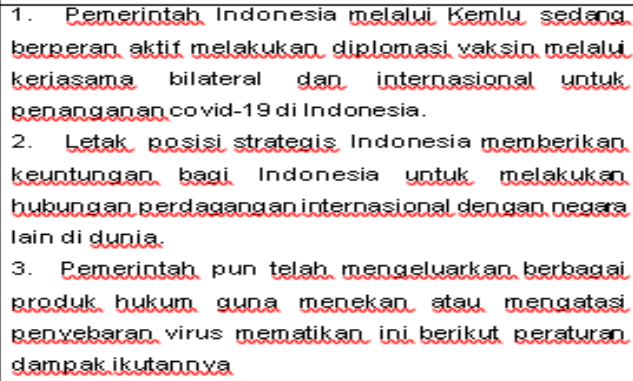 \\
\hline
\end{tabular}

\begin{tabular}{|c|c|}
\hline $\begin{array}{l}\text { Faktor } \\
\text { internal }\end{array}$ & 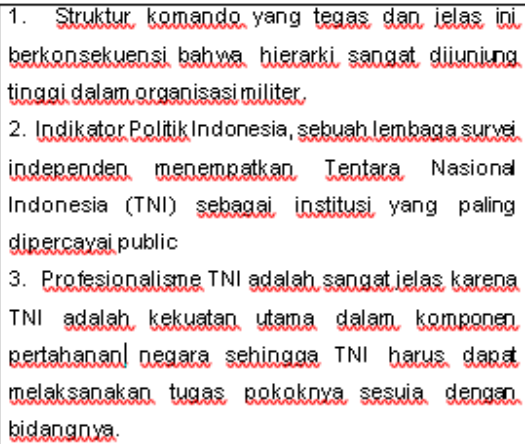 \\
\hline Peluang & $\begin{array}{l}\text { 1. Keriasama bilateral dan internasiong } \\
\text { Indonesia. } \\
\text { 2. Kebijakan dan penetapan undang-undang } \\
\text { kesehatan } \\
\text { 3. TNI sebagai organisasi yang dipercayarakxat } \\
\text { 4. Profesionalitas TNI. }\end{array}$ \\
\hline Kendala & $\begin{array}{l}\text { 1. Perdagangan internasional Indonesia di } \\
\text { tengah pandemiCovid-19. } \\
2 . \quad \text { Struktur komando TNI yang ielas gan tegas } \\
\text { melalui hierarki yang diuniungtinggi }\end{array}$ \\
\hline
\end{tabular}




\begin{tabular}{|c|c|}
\hline $\begin{array}{l}\text { Indikatoc } \\
\text { kebectasisilan }\end{array}$ & 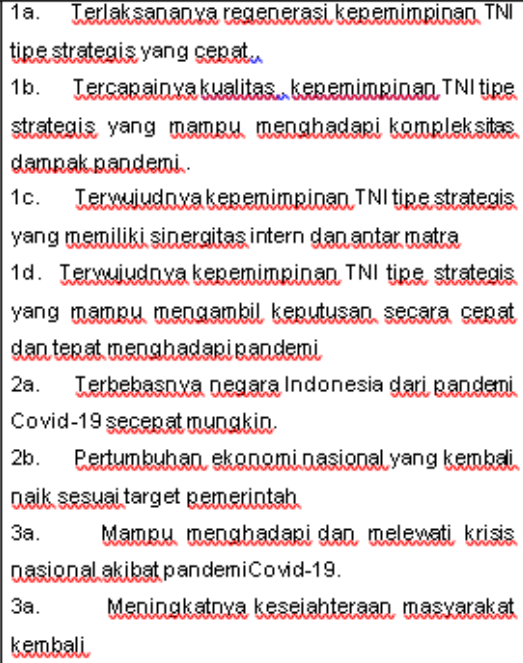 \\
\hline
\end{tabular}

\section{Kesimpulan}

Berdasarkan dari uraian pembahasan dan pemecahan permasalahan yang ditemukan terkait implementasi kepemimpinan TNI tipe strategis dalam percepatan penanganan Covid-19 dan pemulihan ekonomi nasional guna terwujudnya Indonesia tangguh, maka dapat ditarik beberapa kesimpulan sebagai berikut:

a. Untuk memecahkan permasalahan terkait regenerasi kepemimpinan TNI tipe strategis yang berjalan lambat maka dirumuskan strategi yaitu mengimplementasikan regenerasi kepemimpinan TNI tipe strategis yang cepat melalui internalisasi nilai-nilai Pancasila dalam melaksanakan tugas pokok dan pelaksanaan 11 Asas Kepemimpinan TNI dengan cara pendidikan dan pelatihan serta doktrinasi sejak dini dalam percepatan penanganan Covid-19 dan pemulihan ekonomi nasional guna terwujudnya Indonesia tangguh

b. Untuk memecahkan permasalahan terkait kualitas kepemimpinan TNI tipe strategis yang belum mampu menghadapi kompleksitas dampak pandemi Covid-19 maka dirumuskan strategi yaitu mengimplementasikan kualitas kepemimpinan TNI tipe strategis yang mampu menghadapi kompleksitas dampak pandemi melalui peningkatan keunggulan kompetitif dengan cara membangun kompetensi inti di pendidikan formal maupun informal dalam percepatan penanganan Covid-19 dan pemulihan ekonomi nasional guna terwujudnya Indonesia tangguh

c. Untuk memecahkan permasalahan terkait kepemimpinan TNI tipe strategis yang belum memiliki sinergitas internal dan eksternal matra maka dirumuskan strategi yaitu 
mengimplementasikan kepemimpinan TNI tipe strategis yang memiliki sinergitas internal dan eksternal matra melalui pelaksanaan tugas pokok dan pembangunan tim dengan cara sosialisasi, komunikasi, doktrinisasi dan koordinasi internal dan eksternal dalam percepatan penanganan Covid-19 dan pemulihan ekonomi nasional guna terwujudnya Indonesia tangguh

d. Untuk memecahkan permasalahan terkait kepemimpinan TNI tipe strategis yang belum mampu mengambil keputusan secara cepat dan tepat dalam menghadapi Covid-19 maka dirumuskan strategi yaitu mengimplementasikan kepemimpinan TNI tipe strategis yang memiliki kemampuan mengambil keputusan secara cepat dan tepat melalui pemikiran strategis dan penentuan prioritas yang tepat dengan cara analisis problem solving, evaluasi, inovasi dan koordinasi lintas organisasi dalam percepatan penanganan Covid-19 dan pemulihan ekonomi nasional guna terwujudnya Indonesia tangguh.

\section{Saran}

Dari uraian kesimpulan di atas, maka tim penulis memberikan beberapa saran untuk implementasi kepemimpinan TNI tipe strategis dalam percepatan penanganan Covid-19 dan pemulihan ekonomi nasional guna terwujudnya Indonesia tangguh yaitu:

a. Agar Mabes TNI dan angkatan membentuk perwira-perwira muda agar memiliki pemikiran strategis selanjutnya mampu tampil sebagai pemimpin sedini mungkin dalam setiap kesempatan yang ada.

b. Agar Mabes TNI dan angkatan meningkatkan mutu pendidikan di semua Lemdik dengan materi yang sesuai perkembangan jaman dan teknologi modern.

C. Agar Mabes TNI dan angkatan menanamkan pemikiran yang global atau universal kepada para prajurit melalui doktrin-doktrin yang diberikan sejak dini.

d. Agar Mabes TNI dan angkatan menyelenggarakan pelatihan dan kursus problem solving secara rutin dan intens untuk membentuk pemimpin yang mampu berpikir cepat dan tepat dalam mengambil keputusan di segala situasi dan kondisi

\section{Daftar Pustaka}

\section{A. Sumber buku dan barang cetakan}

Hardi Alunaza SD, Diplomasi Vaksin Covid-19 Pemerintah Indonesia, Dosen Prodi Ilmu Hubungan Internasional Fisip Universitas Tanjungpura, Lintas Pakar, 9 November 2020 
Indrawan WS, Kamus Lengkap Bahasa Indonesia, Jombang: Lintas Media

Nadhira Salsabila, Perubahan yang Terjadi Dalam Masyarakat Sebagai Dampak dari COVID-19, Fakultas Ilmu Sosial dan Ilmu Politik Universitas Brawijaya, May 12, 2020

Sarlito Wirawan Sarwono, 2005, Psikologi Sosial: Psikologi Kelompok dan Psikologi Terapan, Balai Pustaka Jakarta

\section{B. Sumber internet}

Asmara Gian Chandra,'Kepercayaan Warga RI ke TNI Tertinggi, Presiden nomor 2, CNBC Indonesia, diakses pada hari Sabtu, 20 Maret 2021, https://www.cnbcindonesia.com/news/20210210120628-4-222401/kepercayaan-warga-rike-tni-tertinggi-presiden-nomor-2,

Aldi M. Alizar dan Yusdi Usman, Kompleksitas Penanganan COVID-19, diakses pada hari Sabtu, 20 Maret 2021 https://iap2.or.id/kompleksitas-penanganan-covid-19/,

Darma Benny, "Survei Charta Politika:TNI, Lembaga dengan tingkat kepercayaan tertinggi, Kompas.com, diakses pada hari Sabtu, 20 Maret 2021 https:/nasional.kompas.com/read/2020/07/22/19095841/survei-charta-politika-tnilembaga-dengan-tingkat-kepercayaan-tertinggi, indonesiadefense.com, memimpin-tentara-milenial-tni-al, diakses pada hari Sabtu, 20 Maret 2021, https://indonesiadefense.com/memimpin-tentara-milenial-tni-al/,

mediaindonesia.com, Politik dan hukum, diakses pada hari Sabtu, 21 Maret 2021, https://mediaindonesia.com/politik-dan-hukum/384826/rapim-tni-polri-2021-bahaspenanganan-covid-19

Muchlisin Riadi, Pengertian dan Tahapan Pemecahan Masalah, April 23, 2016, https://www.kajianpustaka.com/2016/04/pengertian-dan-tahapan-pemecahanmasalah.html

Nurhadi, "Kepemimpinan Strategis dan Manajemen Perubahan : Tinjauan pada organisasi

Sekretariat Jenderal Majelis Permusyawaratan Rakyat Republik Indonesia”, diakses pada hari Sabtu, 6 Maret 2021, https:/www.kompasiana.com/habsulnurhadi/,

Puspen TNI, "11 Asas Kepemimpinan" diakses pada hari Jumat, 19 Maret 2021, https://www.tni.mil.id/pages-8-11-asas-kepemimpinan.html, 
Puspen TNI, Panglima TNI : Soliditas dan Sinergi TNI-Polri Mampu Jaga Persatuan dan Kesatuan Bangsa, Senin, $15 \quad$ Februari https://ppid.tni.mil.id/view/32438537/panglima-tni-soliditas-dan-sinergi-tni-polrimampu-jaga-persatuan-dan-kesatuan-bangsa.html

presiden_jokowi_berikan_arahan_pada_rapim_tni_polri_tahun_2021, diakses pada hari Sabtu, 20

Maret

2021,https://www.setneg.go.id/baca/index/presiden_jokowi_berikan_arahan_pada_rapim _tni_polri_tahun_2021,

Suryanto, Venny. "Ini dua scenario IMF terkait pemulihan ekonomi global dari pandemic covid-19”, Diakses Pada tanggal 21Maret 2021, https://nasional.kontan.co.id/news/ini-2skenario-imf-terkait-pemulihan-ekonomi-global-dari-pandemi-covid-19

Sendari, Ayu, Anugerah, Implementasi adalah Pelaksanaan Tujuan, Pahami Pengertian dan Contohnya" diakses pada hari Rabu, 17 Maret 2021, https://hot.liputan6.com/read/4478774/implementasi-adalah-pelaksanaan-tujuan-pahamipengertian-dan-contohnya,

Treasury, "Program PEN dari Pemerintah", diakses pada hari Rabu, 17 Maret 2021, https://www.unida.ac.id/treasury/artikel/program-pen-dari-pemerintah.html,

Utami, Anindya, Fajria, “Apa Itu Pandemi”, diakses pada hari Rabu, 17 Maret 2021, https://www.wartaekonomi.co.id/read276620/apa-itu-pandemi,

Wall Street English, "Gaji lebih dalam mengenai pengertian kepemimpinan dan tipetipenya" diakses pada hari $\quad$ Rabu, 17 Maret 2021,https:/www.wallstreetenglish.co.id/business-and-career/pengertian-kepemimpinandan-tipe-pemimpin/ 